\title{
COMPARATIVE ANALYSIS OF ENVIRONMENTAL PERFORMANCE OF AN OFFICE BUILDING USING BREEAM AND GBL
}

\author{
WEI CHENG ${ }^{1}$, BEHZADSODAGAR $^{2} \&$ FEIFEISUN $^{3}$ \\ ${ }^{1}$ School of Urban and Architecture, Wuhan University of Science and Technology, China. \\ ${ }^{2}$ School of Architecture and Design, University of Lincoln, UK. \\ ${ }^{3}$ Department of Energy and Environmental Design, NPS Group, UK.
}

\begin{abstract}
With rapid economic growth and urban expansion in China, the Chinese building sector is now facing the huge challenge of balancing its energy demand and pollution. In order to minimise the environmental impact, the Ministry of Housing Urban-Rural Development (MOHURD) has set an ambitious energy reduction target requiring that $30 \%$ of all new constructions to be green by 2020 . This paper presents comparative analysis of two environmental rating systems: the latest version of Chinese Green Building Label (GBL 2014) released by the MOHURD in order to promote the market transformation of green buildings and Building Research Establishment Environmental Assessment Method (BREEAM 2014), the widely recognised environmental assessment methodology in the global construction industry. To compare the two environment assessment standards, a public office building currently under construction in Fujian (China) has been used as a case-study to rate its environmental credentials using both BREEAM and GBL.

Results have shown that although both standards use a similar methodology, they require different levels of input data and may result in differentratings for the same building.

Keywords: BREEAM, carbon emissions, energy consumption, environmental assessment methods, environmental impacts, GBL, green buildings, LCA.
\end{abstract}

\section{INTRODUCTION}

The construction industry is a major contributor to climate change [1] as it is responsible for almost half of the global greenhouse gases and consumes $40 \%$ of the materials entering the global economy $[2,3]$. The effect of carbon emissions on climate change can arguably be seen as the greatest impact and therefore of the most urgent priority [4]. As a result the construction industry has become increasingly concerned with understanding the whole life impact of buildings as it is increasing required to declare the greenhouse gas (GHG), carbon footprint or business $\mathrm{CO}_{2}$ emissions [5]. In addition to investigating and monitoring the effects of buildings on climate change, it is also important for the research community to investigate the effects of climate change on future energy consumptions of buildings as consumptions will change under future climate scenarios [6]. As worldwide population grows and hence more buildings will be needed, one may assume that the construction industry will continue to increase its carbon dioxide emissions unless it changes its practice [4]. This has resulted in energy efficiency in buildings to become a main criterion for energy policy in many countries. 
Table 1: Classification of building environmental assessment methods.

\begin{tabular}{|c|c|c|c|c|c|c|}
\hline \multicolumn{3}{|c|}{ Assessment tool } & Tool type & Country & Developer & Year \\
\hline \multicolumn{3}{|l|}{ BEES } & LCA & USA & $\begin{array}{l}\text { U.S. National } \\
\text { Institute of Standards } \\
\text { and Technology }\end{array}$ & 2002 \\
\hline \multicolumn{3}{|l|}{ ATHENTM } & LCA & Canada & $\begin{array}{l}\text { ATHENA Sustainable } \\
\text { Material Institute }\end{array}$ & 1997 \\
\hline \multicolumn{3}{|l|}{ BEAT } & LCA & Denmark & $\begin{array}{l}\text { Danish Building } \\
\text { Research Institute }\end{array}$ & 1999 \\
\hline \multicolumn{3}{|l|}{ Eco-Quantum } & LCA & Netherlands & $\begin{array}{l}\text { IVAM, University of } \\
\text { Amsterdam }\end{array}$ & 1999 \\
\hline \multicolumn{3}{|l|}{ BREEAM } & CBT & UK & $\begin{array}{l}\text { Building Research } \\
\text { Establishment (BRE) }\end{array}$ & 1990 \\
\hline \multicolumn{3}{|l|}{ LEED } & CBT & USA & $\begin{array}{l}\text { U.S. Green Building } \\
\text { Council }\end{array}$ & 1998 \\
\hline Green Star & CBT & Australia & \multicolumn{2}{|c|}{$\begin{array}{l}\text { Green Building } \\
\text { CouncilAustralia }\end{array}$} & 2003 & \\
\hline CASBEE & CBT & Japan & \multicolumn{2}{|c|}{$\begin{array}{l}\text { Japan Sustainable } \\
\text { Building Consortium }\end{array}$} & 2004 & \\
\hline
\end{tabular}

In this context, the concept of green building plays a significant role in focusing on increasing energy efficiency, sustainable use of resources and moreover enhancing health and wellbeing of building users. In order to assess the environmental performance of the design and build, a number of codes, standards and assessment rating systems have been developed. The codes, standards and procedures have created lively debates and increase awareness within the building industry globally about the actions required to tackle climate change [4]. For example, the EU proposed the Energy Performance Buildings Directive (EPBD)

In 2002 to monitor and to reduce energy use, Brunsgaard et al. [7] analysed how the main EPBD was implemented by EU participating countries. Sharifi and Murayama [8] proposed a review of 7 well-known building environmental assessment tools worldwide with a view to introduce a framework for evaluating the effectiveness of existing tools. Haapio and Viitaniemi [9] analysed and categorised 16 existing building environmental assessment toolsfocusing on the tools developed in Europe and North America. According to Ali and Al Nsairat [10], there are two types of building environmental assessment tools: (i) method based on criteria-based tools (CBT) and (ii) method based on the Life Cycle Assessment (LCA). Table 1 lists a few widely used assessment tools using CBT or LCA approaches.

The aim of LCA method is to evaluate the environmental impact of products and processes during their whole life span from cradle to grave [11], as used for example in assessment tools such as BEES (Building for Environment and Economic Sustainability,USA), ATHENA $^{\mathrm{TM}}$ (Canada), BEAT (Building Environmental Assessment Tool, Denmark) and Eco-Quantum (Netherlands).LCA methods can be used as a decision making support to analyse complex and different sets of alternatives during the design phase with the purpose of optimising materials, energy use,waste management and transportation options. Because of very specific and technical language of most assessment toolsspecialists professions are usu- 
ally their main user groups [10, 12] limiting the wide spread use of tools as most stake holders and decision-makers in the building industry are not specialists enough to initiate the assessment process in all projects. It is therefore crucial to facilitate the use of assessment tools and also promote use of intelligible assessment tools capable of creating easy and simple interaction with potential clients on the market [13]. To achieve truly sustainable buildings there must be a co-coordinated approach involving all stake holders including the client, the industry and local authorities and government [4]. It is also important to realise that in order to minimise carbon emissions, assessments should be carried out at the outset of the design when refinement of design strategies and options have the maximum potential of reducing whole life emissions [5]. Ford et al. [14] argue that without the involvement of the building users (clients) in the design to identify their needs and goals it will be difficult to judge which of energy saving concepts and measures perform well and which do not work at all.

As a 'checklist approach', criteria-based tools (CBT) are more widely accepted and globally used throughout the life-cycle of buildings [15]. To this end, this study analyses the potential of CBT in the environmental assessment of buildings.

CBT methods are based on a system of allocating points to determine credits and classesby evaluating environmental loads [10]. Among the first criteria-based environmental assessment tools is BREEAM (Building Research Establishment Environmental Assessment Method) which was established by the Building Research Establishment (BRE) in the UK in 1990. BREEAM has been used to assess the environmental credentials of buildings over 70 countries worldwide [16]. LEED (Leadership in Energy and Environmental Design) is another widely used assessment tool developed by the U.S. Green Building Council(USGBC) in 1998 with registered projects in covers 30 different countries [17]. Another CBT is the Green Star, a national voluntary environmental rating tool which was launched in 2003 by the Green Building Council of Australia (GBCA) [18]. In Japan, CASBEE(Comprehensive Assessment System for Building Environmental Efficiency) was set up by the Japan Sustainable Building Consortium (JSBC) in 2004 aiming to promote eco-efficient buildings by evaluating the environmental loads and the environmental quality and performance during the life cycle [19].

One of the reasons for comparing GBL and BREEAM in this paper is that an increasing number of buildings are certificated under BREEAM in China as well as due to the fact that GBL2014 is developed based on principles and methodology used in BREEAM.

\section{AIMS AND OBJECTIVES}

The aim and scope of this paper is to review the role of assessment methods in the design and procurement of sustainable buildings and to compare the predicted performance of an office building under construction in China using two widely used assessments methodsin China, i.e. BREEAM and GBL.

\section{SCOPE AND METHODOLOGY}

The research uses quantitative analyses and investigations. BREEAM and GBL rating methods have been examined and used for assessing the sustainability credentials of a case study office building in China. BREEAM has provided a benchmark for a range of building types in the UK. New rating of Outstanding was introduced in 2008 [16] to further reward the best examples. The use of whole life assessment tools are becoming more popular as new buildings constructed to more stringent energy efficiency targets will have a higher ratio of embodied emissions to operational, and this situation will only become more acute as both 
domestic and non-domestic buildings are designed to meet zero carbon targets [20].Even in buildings designed to be zero carbon in use and attempt to have low embodied emissions by substituting alternative materials such as replacing cement with lime, embodied emissions remain significant [21].

BREEAM assesses the environmental performance of design and build by allocating scores to nine technical sections. The sections are management, health and wellbeing, energy, transport, water, materials, waste, land use and ecology, pollution. Scores gained from each section are weighted by the 'environmental weightings', which reflects the relative importance of each section.The weighted scores are then added up to obtain the overall score, which has a base of 100 points. The category 'Innovation' can be achieved with 10 additional points [16].The number of points obtained determines the final level of the certification. There are five progressive levels of certification: Pass, Good, Very Good, Excellent and Outstanding (Table 2).

In 2006, the Chinese Government released the first national green building assessment standard-GBL. As a CBT, it was developed by Society for Urban Studies and administrated by the Ministry of Housing Urban-Rural Development(MOHURD). The new version 2014 of this standard came into force on 1st January 2015 in order to help achieve the national target in China requiring 30\% of all new constructions to be green by 2020 [22]. GBL is classified into five sections being: Landscape, Energy efficiency, Water efficiency, Material and resource, Indoor environment. Similar to BREEAM, GBL certification is a point-based score rating with a percentage weightingsystem. Likewise BREEAM, 'Innovation' can also be gained in GBL with 10 additional points. There are three 'classes' of certifications in GBL being: one-star, two-star or three-star, with three-star being the highest achievement (Table 2).

Figure 1 illustrates the sections in BREEAM and GBL from which scores may be obtained. Due to different number of sections in each method and in order to make the comparison

Table 2: Sections and levels of BREEAM and GBL.

\begin{tabular}{lll}
\hline & BREEAM & GBL \\
\hline Categories and & Management 12\% & Landscape 16\% \\
& Health and Wellbeing 15\% & Energy efficiency 28\% \\
Energy 15\% & Water efficiency 18\% \\
& Transport 9\% & Material and resource 19\% \\
& Water 7\% & Indoor environment 19\% \\
& Materials 13.50\% & Innovation (additional) 10\% \\
& Waste 8.50\% & \\
& Land use and ecology 10\% & \\
& Pollution 10\% & \\
& Innovation(additional) 10\% & \\
Levels of certification & Pass 30-44 & one-star $\star 50-59$ \\
and score & Good 45-54 & two-star $\star \star 60-79$ \\
& Very Good 55-69 & \\
& Excellent 70-84 & \\
& Outstanding 85+ & \\
\hline
\end{tabular}


Table 3: Redistribution of credits to the new sections for BREEAM.

\begin{tabular}{|c|c|c|c|}
\hline \multicolumn{3}{|c|}{ Land Use and Ecology } & \multirow{2}{*}{$\begin{array}{l}\mathbf{1 0 . 0 0 \%} \\
2.00 \%\end{array}$} \\
\hline$\bullet$ & LE01 & Site selection & \\
\hline$\bullet$ & LE02 & $\begin{array}{l}\text { Ecological value of site and protection of ecological } \\
\text { features }\end{array}$ & $2.00 \%$ \\
\hline$\bullet$ & LE03 & Minimising impact on existing site ecology & $2.00 \%$ \\
\hline$\bullet$ & LE04 & Enhancing site ecology & $2.00 \%$ \\
\hline \multirow[t]{2}{*}{$\bullet$} & LE05 & Long term impact on biodiversity & $2.00 \%$ \\
\hline & \multicolumn{2}{|c|}{ Transport } & $9.00 \%$ \\
\hline$\bullet$ & Tra01 & Public transport accessibility & $3.75 \%$ \\
\hline$\bullet$ & Tra02 & Proximity to amenities & $1.50 \%$ \\
\hline$\bullet$ & Tra03 & Cyclist facilities & $1.50 \%$ \\
\hline$\bullet$ & Tra04 & Maximum car parking capacity & $1.50 \%$ \\
\hline \multirow[t]{2}{*}{$\bullet$} & Tra05 & Travel plan & $0.75 \%$ \\
\hline & Energy & & $15.00 \%$ \\
\hline$\bullet$ & Ene01 & Reduction of energy use and carbon emissions & $5.81 \%$ \\
\hline$\bullet$ & Ene02 & Energy monitoring & $0.97 \%$ \\
\hline$\bullet$ & Ene03 & External lighting & $0.48 \%$ \\
\hline$\bullet$ & Ene04 & Low carbon design & $1.45 \%$ \\
\hline$\bullet$ & Ene05 & Energy efficient cold storage & $0.97 \%$ \\
\hline$\bullet$ & Ene06 & Energy efficient transportation systems & $1.45 \%$ \\
\hline$\bullet$ & Ene07 & Energy efficient laboratory systems & $2.42 \%$ \\
\hline$\bullet$ & Ene08 & Energy efficient equipment & $0.97 \%$ \\
\hline \multirow[t]{2}{*}{$\cdot$} & Ene09 & Drying space & $0.48 \%$ \\
\hline & Water & & $7.00 \%$ \\
\hline$\bullet$ & Wat01 & Water consumption & $3.89 \%$ \\
\hline$\bullet$ & Wat02 & Water monitoring & $0.78 \%$ \\
\hline$\bullet$ & Wat03 & Water leak detection & $1.55 \%$ \\
\hline \multirow[t]{2}{*}{$\bullet$} & Wat04 & Water efficient equipment & $0.78 \%$ \\
\hline & Materi & & $13.50 \%$ \\
\hline$\bullet$ & Mat01 & Life cycle impacts & $5.80 \%$ \\
\hline$\bullet$ & Mat02 & Hard landscaping and boundary protection & $0.96 \%$ \\
\hline$\bullet$ & Mat03 & Responsible sourcing of materials & $3.86 \%$ \\
\hline$\bullet$ & Mat04 & Insulation & $0.96 \%$ \\
\hline$\bullet$ & Mat05 & Designing for durability and resilience & $0.96 \%$ \\
\hline \multirow[t]{2}{*}{$\bullet$} & Mat06 & Material efficiency & $0.96 \%$ \\
\hline & Health & and Wellbeing & $15.00 \%$ \\
\hline$\bullet$ & Hea01 & Visual comfort & $4.09 \%$ \\
\hline$\bullet$ & Hea02 & Indoor air quality & $3.41 \%$ \\
\hline$\bullet$ & $\mathrm{Hea03}$ & Safe containment in laboratories & $1.36 \%$ \\
\hline
\end{tabular}


Table 3: (continued)

\begin{tabular}{|c|c|c|c|}
\hline$\bullet$ & $\mathrm{Hea04}$ & Thermal comfort & $2.05 \%$ \\
\hline$\bullet$ & Hea05 & Acoustic performance & $2.73 \%$ \\
\hline \multirow[t]{2}{*}{$\bullet$} & Hea06 & Safety and security & $1.36 \%$ \\
\hline & \multicolumn{2}{|c|}{ Pollution } & $10.00 \%$ \\
\hline$\bullet$ & Pol01I & mpact of refrigerants & $2.31 \%$ \\
\hline$\bullet$ & Pol02 & NOx emissions & $2.31 \%$ \\
\hline$\bullet$ & Pol03 & Surface water run-off & $3.84 \%$ \\
\hline$\bullet$ & Pol04 & Reduction of night time light pollution & $0.77 \%$ \\
\hline \multirow[t]{2}{*}{$\bullet$} & Pol05 & Reduction of noise pollution & $0.77 \%$ \\
\hline & \multicolumn{2}{|l|}{ Waste } & $8.50 \%$ \\
\hline$\bullet$ & Wst01 & Construction waste management & $3.80 \%$ \\
\hline$\bullet$ & Wst02 & Recycled aggregates & $0.94 \%$ \\
\hline$\bullet$ & Wst03 & Operational waste & $0.94 \%$ \\
\hline$\bullet$ & Wst04 & Speculative floor and ceiling finishes & $0.94 \%$ \\
\hline$\bullet$ & Wst05 & Adaptation to climate change & $0.94 \%$ \\
\hline \multirow[t]{7}{*}{$\bullet$} & Wst06 & Functional adaptability & $0.94 \%$ \\
\hline & \multicolumn{2}{|c|}{ Management } & $12.00 \%$ \\
\hline & Man01 & Project brief and design & $2.29 \%$ \\
\hline & Man02 & Life cycle cost and service life planning & $2.29 \%$ \\
\hline & Man03 & Responsible construction practices & $3.42 \%$ \\
\hline & Man04 & Commissioning and handover & $2.29 \%$ \\
\hline & Man05 & Aftercare & $1.71 \%$ \\
\hline
\end{tabular}

BREEAM

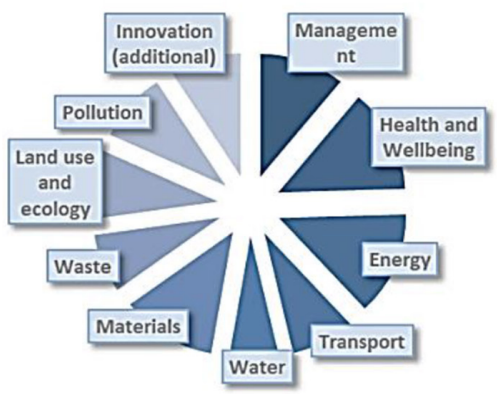

GBL

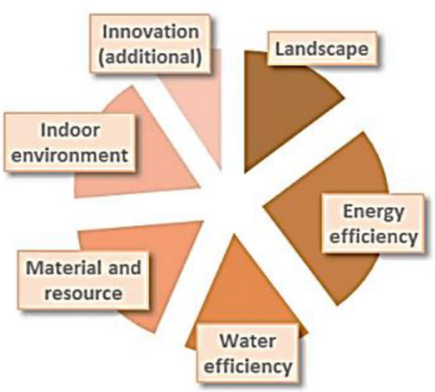

Figure 1: Sections of certification for BREEAM and GBL.

between the two methods more meaningful, five shared sections based on universal environmental impacts were identified for both methods. There are landscape, energy and atmosphere, water, materials, indoor environment. The new weightings (\%scores) were counted by adding up the individual scores of each section for BREEAM (Table 3) and GBL (Table 4) and in accordance with the aspects embedded in the new five sections identified for both methods. 
Table 4: Redistribution of credits to the new sections for GBL.

\begin{tabular}{|c|c|c|c|}
\hline \multicolumn{3}{|c|}{ Landscape } & \multirow{2}{*}{$\begin{array}{l}16.00 \% \\
5.44 \%\end{array}$} \\
\hline$\bullet$ & Lan01 & Landutilization & \\
\hline$\bullet$ & Lan02 & Outdoor environment & $2.88 \%$ \\
\hline$\bullet$ & Lan03 & Transportation and public services & $3.84 \%$ \\
\hline$\bullet$ & Lan04 & Site design and site ecology & $3.84 \%$ \\
\hline \multicolumn{3}{|c|}{ Energy efficiency } & $28.00 \%$ \\
\hline$\bullet$ & Ene01 & Building and envelope & $6.16 \%$ \\
\hline$\bullet$ & Ene02 & HAVC & $10.36 \%$ \\
\hline$\bullet$ & Ene03 & Lighting and electrical system & $5.88 \%$ \\
\hline$\bullet$ & Ene04 & Energy utilisation & $5.60 \%$ \\
\hline \multicolumn{3}{|c|}{ Water efficiency } & $18.00 \%$ \\
\hline$\bullet$ & Wat01 & Water-saving system & $6.30 \%$ \\
\hline$\bullet$ & Wat02 & Water-saving utensils and facilities & $6.30 \%$ \\
\hline$\bullet$ & Wat03 & Utilisation of non-traditional water resources & $5.40 \%$ \\
\hline \multicolumn{3}{|c|}{ Material and resources } & $19.00 \%$ \\
\hline - & Mat01 & Material-saving design & $7.60 \%$ \\
\hline$\bullet$ & Mat02 & Material selection & $11.40 \%$ \\
\hline \multicolumn{3}{|c|}{ Indoor environment } & $19.00 \%$ \\
\hline$\bullet$ & Ind01 & Indoor acoustic environment & $4.18 \%$ \\
\hline$\bullet$ & Ind02 & Indoor lighting environment & $4.75 \%$ \\
\hline & Ind03 & Indoor thermal environment & $3.80 \%$ \\
\hline & Ind04 & Indoor air quality & $6.27 \%$ \\
\hline
\end{tabular}

Table 5: New sections and score (\%weighting) for BREEAM and GBL.

\begin{tabular}{|c|c|c|c|c|c|}
\hline & Landscape & $\begin{array}{l}\text { Energy and } \\
\text { atmosphere }\end{array}$ & Water & Material & $\begin{array}{c}\text { Indoor } \\
\text { environment }\end{array}$ \\
\hline BREEAM & $24.4(27.7 \%)$ & $19.6(22.3 \%)$ & $7(8.0 \%)$ & $22(25.0 \%)$ & $15(17.0 \%)$ \\
\hline GBL & $16(16.0 \%)$ & $28(28.0 \%)$ & $18(18.0 \%)$ & $19(19.0 \%)$ & $19(19.0 \%)$ \\
\hline
\end{tabular}

The colour coding used in Tables 3 and 4 relates to the five new sections as shown in Table 5. The new five sections were standardised on the basis of 100 once the new weightings (\%scores) were set up (Table 5).

The performance reactivity for BREEAM and GBL is shown on the histogram in Fig.2. BREEAM allocates more points to the landscape section as compared with the other 4 sections. Table 3 demonstrates there are 13 issues included in thelandscape(red colour) allowing for factors related to the sustainability of the landscape choice such as ecology and amenity issues. In GBL more attention has been paid to land utilisation (Lan01) accounting for $34 \%$ of the total scores allocated to the landscape section (Table 4). The 


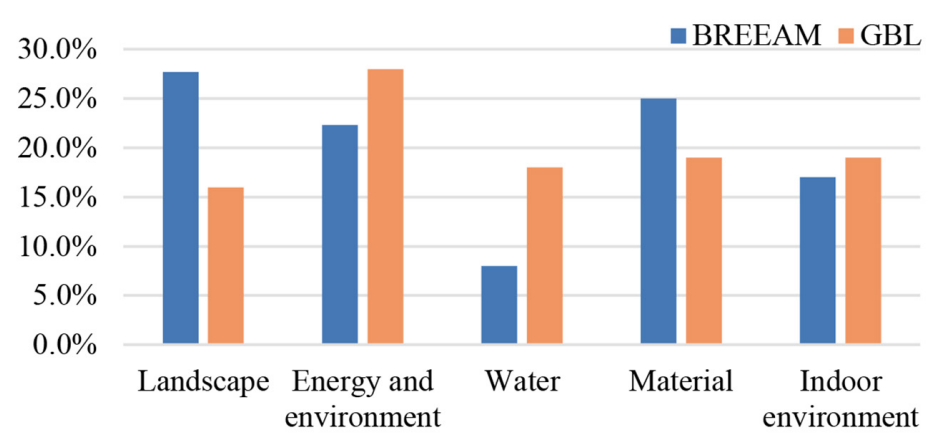

Figure 2: Comparison new sections between BREEAM and GBL.

main reason for emphasising this aspect in GBL is due to the shortage of available land in China.

The energy and atmosphere performance in BREEAM emphasises on reduction of greenhouse gas emissions, such as $\mathrm{CO}_{2}$ and $\mathrm{NO}_{\mathrm{X}}$ [16]. This section in GBL attracts the highest portion of scores, $28 \%$ of total scores (Table 5). There is a considerable difference in the level of scores allocated to water in the two methods. BREEAM focuses on reducing the demand for potable water, while GBL focuses on optimising water-supply. GBL has higher water weighting compared with BREEAM.

Material is the second most prioritised section after landscape in BREEAM in order to minimise the environmental impacts, reducing waste and promoting sustainable sourcing of materials. Indoor environment section relating to lighting, acoustics, thermal and air quality, is a common area in both methods and the weightings are relatively similar.

In our study, we have not included management and innovation in the composition of the new five sections. This is due to the fact that management, a category existed in BREEAM for managing the service quality, is not linked to any environmental credit. As for innovation, it is an additional category existed in both BREEAM and GBL. So by excluding the management and innovation in our analysis, the quantifiable results are not affected in terms of environmental sustainability. This has resulted for the total maximum possible scores achievable in the five new sections in BREEAM equate to 88 while the corresponding figure is 100 in CBL (Figs 4 and 5).

\section{PILOT STUDY}

The building selected for the study is $105 \mathrm{~m}$ tall, 30 story public office building (named building C82), located in Fujian, China, which is currently under construction (2016) and due to be completed by the end of 2017 (Fig. 3). Table 6 lists some characteristics of the building. The area of the site is 13,300 square meters. The building has a total floor area of 109,860 square meters, of which 25,678 square meters is underground. Four public transport stations are near the entrance of the site, with walking distances less than 500 meters to the building. The building is made of reinforced concretewithfully glass curtain walling facade. The building is equipped with varied refrigerant volume (VRV) air conditioning system with condensation heat recovery fresh air unit. Rainwater is collected and stored in anunderground tank for reuse as gray water after being flocculated, filtered and disinfected, for purpose such as irrigating the landscape, road cleaning and garagewashing. Gray water is not used for flushing toilets.

BREEAM and GBL require energy performance of the design against a 'Notional building' by using the approved simulation tools according to each standard [23, 24]. For BREEAM, 


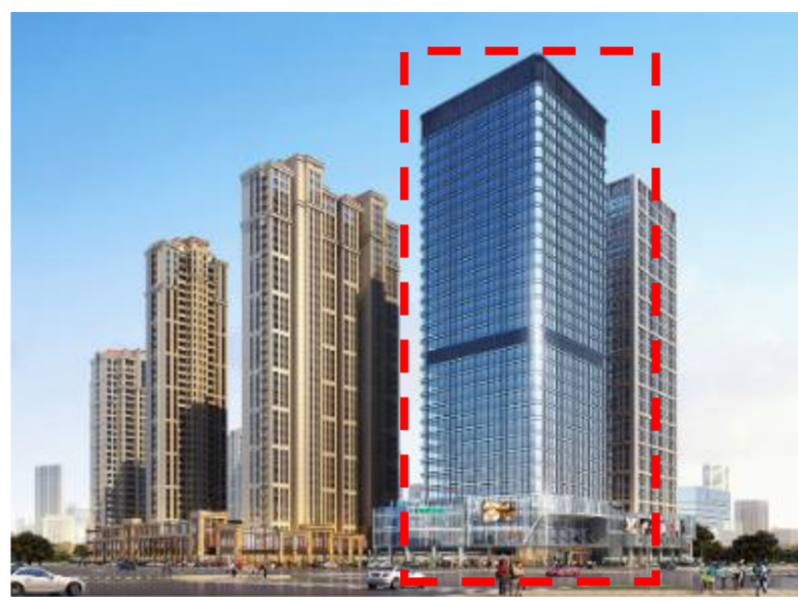

Figure 3: The case building- 'C82'.

Table 6: Summary information for 'C82.

\begin{tabular}{ll}
\hline Location & Fujian,China \\
\hline Gross floor area & $109,860 \mathrm{~m}^{2}$ \\
Site area & $13,300 \mathrm{~m}^{2}$ \\
External wall U-value & $1.02 \mathrm{~W} / \mathrm{m}^{2} \mathrm{~K}$ \\
Window U-value & $2.25 \mathrm{~W} / \mathrm{m}^{2} \mathrm{~K}$ \\
(include glass curtain wall) & \\
Roof U-value & $0.573 \mathrm{~W} / \mathrm{m}^{2} \mathrm{~K}$ \\
Heat/cooling generator & Heat pump \\
Thermostat & Summer $25^{\circ} \mathrm{C}$ \\
settings(designed) & Winter $18^{\circ} \mathrm{C}$ \\
\hline
\end{tabular}

the 'Notional building' has been defined in the NCM2013 [25] and the simulation software 'Energyplus' was used to examine energy performance of the building. For GBL, the 'Notional building' has been definedin the national standard GB50189-2015 [24] and 'PKPM', the most widespread software for analysing dynamic energy consumption in China, was applied to evaluate the energy performance of the case study building.

\section{RESULTS AND CONCLUSIONS}

This section discusses the main differences in the composition of total score calculated by BREEAM and GBL methods for the building case study. Table 7 present the results obtained from our analyses. The building is classified as 'Good' with 50.93 points for BREEAM and two-star with 63.66 points for GBL. The correlations between the results for the corresponding categories can be seen in Figs 4-6. The landscape category encourages sustainable land use as well as better access to sustainable means of transport for building users. The two methods appear to show relatively close scores for the landscape category. The case study building has archived a score of 14.63 in BREEAM out of the 
BREEAM for C82 $\square$ Total score

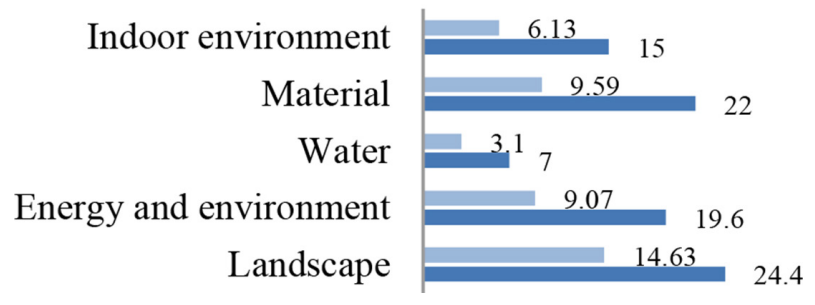

Figure 4: Score achieved in C82 related to maximum score of the new BREEAM's sections.

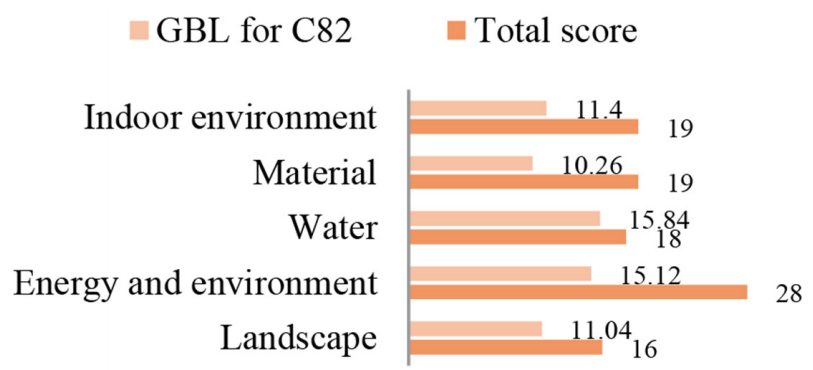

Figure 5: Score achieved in C82 related to maximum score of the new GBL's sections.

Table 7: Results of BREEAM and GBL for the building 'C82' GBL.

\begin{tabular}{lll}
\hline & BREEAM & GBL \\
\hline & Management6.00 & Landscape11.04 \\
& Health and Wellbeing11.04 & Energy efficiency15.12 \\
& Land Use and Ecology5.00 & Water efficiency15.84 \\
& Transport5.25 & Material and resourc- \\
& Energy6.77 & es10.26 \\
Section Score & Water3.88 & Indoor environment11.40 \\
& Material7.71 & Innovation(additional)0 \\
& Waste1.88 & \\
& Pollution7.69 & \\
Final score & Innovation(additional)0 & \\
Rating & $\mathbf{5 0 . 9 3}$ & $\mathbf{6 3 . 6 6}$ \\
\hline
\end{tabular}

maximum available 24.4 (Fig.4) representing 60\% achievement (Fig.6). GBL has estimated a score of 11.04 out of a possible maximum 16 (Fig.5) representing a 70\% achievement (Fig.6).

According to the results for energy and atmosphere section, similar performance is ascribed to the building $\mathrm{C} 82$ by the dynamic simulations, but we can see BREEAM gives fewer points than GBL for this category as seen in Figs 4 and 5. Because the two schemes are based on different energy assessment methods, $46 \%$ of the total scores (9.07 out of 16.9 as in Fig. 4) 


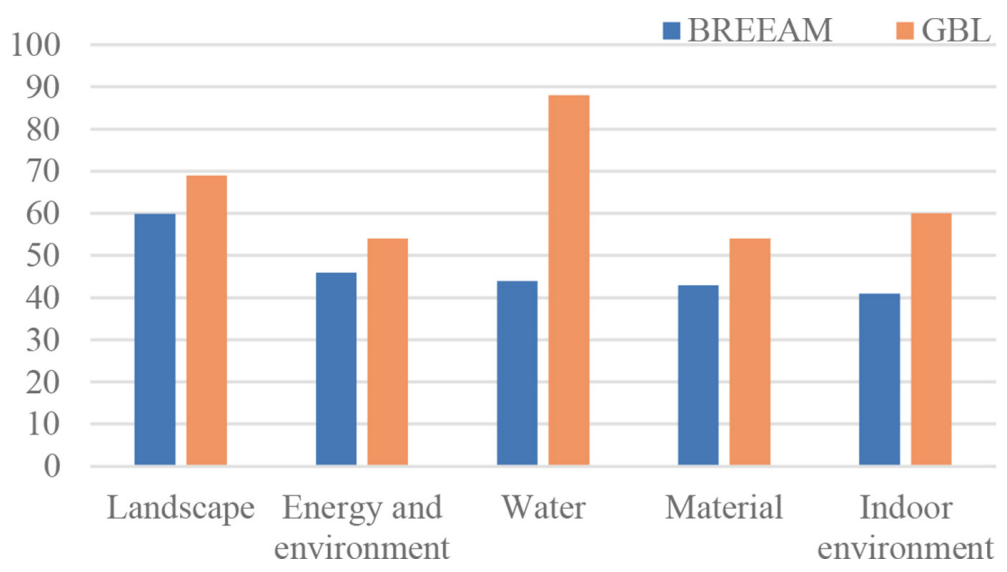

Figure 6: Comparison between BREEAM and GBL results(new sections) for the building of $\mathrm{C} 82$.

are awarded by using BREEAM in comparison with 54\% of the total scores (15.12 out of 28 as in Fig. 5) awarded by GBL (Fig.6).

The biggest difference between the two methods is the results for the section 'water' for the case study building. The reuse of water is highly prioritised by BREEAM, while the percentage of water saved is of concern in GBL. According to GBL requirements, saving water is a practice that has excellent potential for reducing consumption, so the case study building gets a high score for water (15.84 out of 18), while the corresponding score for BREEAM is only 3.1 out of 7 as shown in Figs4 and 5, respectively.

Regarding the section of material, both methods consider the percentage of recyclable materials used and the reduction of waste. BREEAM pays more value to low embodied impact materials over their life. Examining the item of materials $43 \%$ of the score is related to the total in BREEAM while the corresponding figure is $54 \%$ in GBL.

For indoor environment, limited evaluations of acoustic, lighting, thermal and air quality are assessed by both methods. BREEAM covers more details than GBL in the Indoor environment section in general and specifically in the containment and secure use. The case study building in BREEAMachieves only 6.13 points out of a maximum possible 15 representing $41 \%$ while in GBLscores 11.4 out of a maximum possible 19 representing 60\%. The building has achieved a total score of 42.52 out of a possible available 88 points (Fig. 4) representing an overall achievement of $48 \%$ in BREEAM while the corresponding figures in GBLis around $64 \%$ (Fig. 5).

This paper analysed the environmental performance assessment of a case study office building by using two widely used assessment methods, i.e. BREEAM and GBL in China. Among the aims of the study was to compare GBL procedure and its results with those of BREEAM through using both methods in evaluating environmental performance of a case study office building under construction in China. In order to make comparisons between the two methods more compatible and meaningful, it was necessary to devise a new structure within which the credits can be redistributed to five main common sections applicable to both methods. These five new sections are landscape, energy and atmosphere, water, materials, indoor environment, respectively.

The comparison showed that the main objectives of BREEAM and GBL methods are very similar and that generally speaking their assessment and certification are relatively close. The 
two methods, however, allocate different levels of emphasis to different assessment criteria. The results obtained are based on analyses carried out for one case study office building in China and hence cautious should be exercised when applying the results universally.

\section{REFERENCES}

[1] Urge-Vorsatz, D., Harvey, L.D.D., Mirasgedis, S. \& Levine, M.D., Mitigating $\mathrm{CO}_{2}$ emissions from energy use in the world's buildings. Building Research \& Information, 35(4), pp.379-398, 2007. http://dx.doi.org/10.1080/09613210701325883

[2] Asif, M., Muneer, T. \& Kelly, R., Life cycle assessment: a case study of a dwelling home in Scotland. Building and Environment, 42(3), pp.1391-1394, 2007. http://dx.doi.org/10.1016/j.buildenv.2005.11.023

[3] United Nations Environment Programme (UNEP), Buildings: Investing in Energy and Resource Efficiency.UNEP, 2011, available at www.unep.org/greeneconomy/Portals/88/documents/ger/9.0_Buildings.pdf

[4] Sodagar, B. \&Fieldson, R., Towards a low carbon construction practice. Construction Information Quarterly (CIQ) Journal Chartered Institute of Building (CIOB), 10(3), pp.101-108, 2008.

[5] Fieldson, R., Rai, D. \&Sodagar, B., Towards a framework for early estimation of lifecycle carbon footprinting of buildings in the UK. Construction Information Quarterly (CIQ) Journal, Chartered Institute of Building (CIOB), 11(2), pp. 66-75, 2009.

[6] Sun, F., Sodagar, B. \& Bell, J., Building heating consumptions under present and future climate scenarios. PLEA2013 of the 29th Conference on Sustainable Architecture for a Renewable Future, Germany, 2013.

[7] Brunsgaard, C., Dvořáková, P., Wyckmans, A., Stutterecker, W., Laskari, M., Almeida, M., Kabele, K., Magyar, Z., Bartkiewicz, P. \&Op't Veld, P., Integrated energy design Education and training in cross-disciplinary teams implementing energy performance of buildings directive (EPBD). Building and Environment, 72, pp.1-14, 2014. http://dx.doi.org/10.1016/j.buildenv.2013.10.011

[8] Sharifi, A. \& Murayama, A., A critical review of seven selected neighborhood sustainability assessment tools. Environ Impact Assessment Review, 38, pp.73-87, 2013. http://dx.doi.org/10.1016/j.eiar.2012.06.006

[9] Haapio, A. \&Viitaniemi, P., A critical review of building environmental assessment tools. Environ Impact Assessment Review, 28(7), pp.469-482, 2008. http://dx.doi.org/10.1016/j.eiar.2008.01.002

[10] Ali, H.H. \& Al Nsairat, S.F., Developing a green building assessment tool for developing countries- case of Jordan.Build Environment, 44(5), pp.1053-1064, 2009. http://dx.doi.org/10.1016/j.buildenv.2008.07.015

[11] Ortiz, O., Castells, F. \&Sonnemann, G., Sustainability in the construction industry: a review of recent developments based on LCA. Construction Building Materials, 23(1), pp. 28-39, 2009.

http://dx.doi.org/10.1016/j.conbuildmat.2007.11.012

[12] Suzer, O., A comparative review of environmental concern prioritization: LEED vs other major certification systems.Environmental Management, 154, pp. 266-283, 2015. http://dx.doi.org/10.1016/j.jenvman.2015.02.029

[13] Krause, A.L. \& Bitter, C., Spatial econometrics, land values and sustainability: trends in real estate valuation research.Cities, 29(2), pp.19-25, 2012.

http://dx.doi.org/10.1016/j.cities.2012.06.006 
[14] Ford, B., Schiano-Phan, R.\&Zhongcheng, D., The passivhaus standard in European warm climates, Passive-on Project, www.eerg.it/passiveon.org/CD/1.\%20Technical\%20Guidelines/Part\%203/Part\%203.pdf

[15] ZabalzaBribian, I., ArandaUson, A. \&Scarpellini, S., Life cycle assessment in buildings: state-of-the-art and simplified LCA methodology as a complement for building certification. Building Environment, 44(12), pp.2510-2520, 2009.

http://dx.doi.org/10.1016/j.buildenv.2009.05.001

[16] BREEAM,available at www.breeam.com/why-breeam

[17] LEED, available at www.usgbc.org/leed

[18] Green star,available at www.gbca.org.au/faq/green-star

[19] CASBEE, available at www.ibec.or.jp/CASBEE

[20] Fieldson, R. \& Smith, B., Gathering diverse and complex energy use data for monitoring and analysis. London Business Conferences,2007available at www.researchgate. net/publication/237665752

[21] Sodagar, B., Fieldson, R. \& Gilroy Scott, B., Design for sustainable architecture and environments. The International Journal of Environmental Cultural Economic \& Social Sustainability, 4(4), pp.73-84, 2007.

[22] MOHURD, available at www.mohurd.gov.cn/

[23] Schwartz, Y.\&Raslan, R., Variations in results of building energy simulation tools, and their impact on BREEAM and LEED ratings: a case study. Energy \& Buildings, 62(7), pp. 350-359, 2013.

[24] Ministry of Housing Urban-Rural Development (MOHURD), GB50189-2015: Design standard for energy efficiency of public buildings. MOHURD, China, pp.11-15, 2014.

[25] NCM, National Calculation Methodology (NCM) Modeling Guide. Building Research Establishment Ltd, 2013. 